\title{
COMO PENSAR O ELEMENTO SERVIL: O LUGAR DOS LIBERTOS NAS EXPECTATIVAS DAS ELITES APÓS A EMANCIPAÇÃ̃ ${ }^{1}$
}

\author{
Aline Najara da Silva Gonçalves ${ }^{2}$ \\ Álvaro Pereira do Nascimento ${ }^{3}$
} algum tempo debruçou-se sobre o problema do elemento servil. ${ }^{4}$ Entre correrias para acudir mulheres próximas a apresentar seus bebês à luz e seus diversos estudos, Durocher redigiu 25 páginas sobre a emancipação dos escravizados e as publicou na Typographia do

1 Este artigo traz resultados parciais da pesquisa de doutorado em História desenvolvida por Aline Najara da Silva Gonçalves pelo Programa de Pós-Graduação em História Social da UFRRJ, com orientação do professor doutor Álvaro Pereira do Nascimento.

2 Doutoranda em História Social na Universidade Federal Rural do Rio de Janeiro (UFRRJ). alinasigo@gmail.com.

3 Professor associado do campus de Nova Iguaçu da Universidade Federal Rural do Rio de Janeiro (UFRRJ). alvaropn@uol.com.br.

4 Marie Josephine Mathilde Durocher se tornou, na segunda metade do século XIX, a primeira parteira diplomada pela Academia Imperial de Medicina e a primeira mulher a ser recebida como membro titular da Academia. Foi descrita por um jurista àquele período como um "tipo bizarro, uma criatura insexuada [...] com umas barbichas que pendiam de uma berruga no queixo", cf. Neto Geraldes, "Madame Durocher: uma desbravadora", <https://netogeraldes. blogspot.com/2014/03/madame-durocher-e-um-personagem.html >, acessado em 10/01/2020. Parteira e intelectual, escreveu vários livros e se destacou profissionalmente em um país onde as ciências eram preponderantemente um campo masculinizado. Sobre Durocher, cf. Maria Lúcia de Barros Mott, "Madame Durocher, modista e parteira", Revista Estudos Feministas, Ano 2, n. 1 (1994), pp. 101-116; Tânia Salgado Pimenta e Gisele Machado Barbosa, "O ofício de parteira no Rio de Janeiro imperial", Revista de História Regional, 2016, pp. 491-492; "D. Maria Josephine Mathilde Durocher", in Augusto Victorino Alves Sacramento Blake, Diccionario Bibliographico Brazileiro, Rio de Janeiro: Typographia Nacional, 1883, v. 6, p. 233. 
Diário do Rio de Janeiro, à Rua do Ouvidor, nº 67, no atual Centro do Rio de Janeiro. Em seu escrito, cujas palavras eram "filhas" de suas "boas intenções" e seus mais "sinceros desejos", apresentou uma carta aberta ao Barão de Cotegipe, a quem se dirigiu como uma "amiga respeitosa". 5

Conservadora em sua forma de ver o mundo, sua preocupação com os dias futuros era tamanha, chegando a esmiuçar o perfil dos desejados futuros chefes de polícia, que deveriam ser mais enérgicos em relação à "juventude turbulenta, meretrizes, artistas, cocheiros, barqueiros, carregadores, em resumo, a classe baixa". ${ }^{6} \mathrm{Se}$ os que lhes eram contemporâneos falhavam com essa gente, como iriam assegurar-se - ela e tantas outras pessoas de boas famílias - que, libertados os escravizados, a paz reinaria no cotidiano?

Durocher não era caso isolado. A consulta a livretos e manuais publicados entre 1866 e 1871 revelou algumas das expectativas de parte da população livre em relação ao horizonte que se aproximava. Políticos de diferentes esferas do poder, senhores, professores, jornalistas, intelectuais, advogados, parteiras, entre outras pessoas revelaram seus temores e redigiram verdadeiros tratados para enfrentar o problema do elemento servil, no que tange às formas de emancipá-lo e às consequências que adviriam deste processo.

Diversas opiniões surgiram após perceptível inquietação do imperador. Praticamente extinto o tráfico de escravos, em 1850, algumas falas públicas e consultas privadas realizadas por D. Pedro II, no meado da década de 1860, revelavam um monarca interessado em dar um segundo passo, ainda mais ambicioso e perigoso. Determinado em suas convicções, inaugurou uma fase conflituosa em diversas áreas, que se estenderia por mais de trinta anos: a emancipação do elemento servil no Brasil.

Madame Durocher, como mencionado, era mais uma incomodada com a transformação que viria dali por diante, defendida pelo homem mais poderoso do Brasil. A leitura dos opúsculos analisados neste artigo aponta a possibilidade de refletir sobre algo maior que o impacto das

5 Maria Josephine Matilde Durocher, Ideias por coordenar a respeito da emancipação, Rio de Janeiro: Typographia do Diário do Rio de Janeiro, 1871, p. 5, <https://digital.bbm.usp.br/ handle/bbm/4312>, acessado em 24/07/2018. 
leis emancipacionistas sobre o futuro de senhores e escravos durante a segunda metade do século XIX. O que se vislumbra aqui é perceber o horizonte de expectativas de pessoas livres diante da inauguração dos debates em torno da emancipação. O medo que sentiam foi revertido em propostas voltadas para a manutenção de uma sociedade que correspondesse aos costumes e valores construídos e experimentados à luz das hierarquias nobiliárquicas, raciais, sociais, econômicas e de poder presentes naqueles tempos.

Enfim, como seria digerir o jantar com uma boa caminhada pelas ruas do bairro? Quem venderia uma reles vassoura ou a galinha para o almoço? Que mãos arrancariam a semente dos ramos dos cafezais, fruto da revigorante e valiosa bebida sorvida no Brasil e no exterior por milhões de pessoas? Como manter arrumada e asseada a casa do advogado, penteados os cabelos de Capitu, alimentada a família com o sabor dos pratos de Bertoleza? Como seria? O mundo parecia virar paulatinamente de ponta-cabeça, e aquela gente - que dependia do trabalho de pessoas escravizadas, direta ou indiretamente -, certamente ficava atônita com o desenrolar das notícias que vinham da Câmara e do gabinete do imperador, resultando em diversos livretos e manuais que circulavam em gabinetes de políticos, salas de proprietários de escravizados(as) e nos encontros das famílias mais abastadas.

\section{A fala do trono}

Na Sessão Imperial da Assembleia Geral Legislativa de 22 de maio de 1867, sob presidência do Sr. Visconde de Abaeté, Sua Majestade proferiu, às 13 horas, a Fala do Trono aos deputados ali presentes. ${ }^{7}$ Tratava-se de um pronunciamento anual pelo qual o imperador abria os trabalhos da Assembleia Legislativa, expondo um rápido balanço do seu governo

7 No documento registrado nos Annaes do Parlamento Brazileiro do ano de 1867 consta o registro da data 22 de maio de 1866, entretanto, como o projeto de resposta à Fala do Trono foi discutido e publicado na sessão de 27 de maio de 1867, chegamos à conclusão de que houve um erro de digitação e seguimos a data conforme publicado no livro de Fallas do Throno desde o anno de 1823 até o anno de 1889, no qual a data registrada foi 22 de maio de 1867. Cf. Brasil, Assembleia Geral, Câmara dos Deputados, Falas do Trono: desde o ano de 1823 até $o$ ano de 1889, Rio de Janeiro: Imprensa Nacional, 1889, <http://www2.senado.leg.br/ bdsf/handle/id/227319>, acessado em 10/07/2018. 
e suas expectativas para o ano em curso. $\mathrm{O}$ foco do seu discurso foi a guerra contra o Paraguai e os esforços do governo brasileiro, do Exército, da Armada, da Guarda Nacional e dos voluntários da pátria para solucionar o conflito, bem como a busca de meios para sanar os déficits relacionados às despesas com a guerra.

A guerra, os esforços para solucioná-la e a crise financeira eram fios de uma trama que, quando tecida, deixaria evidente um grande nó difícil de desatar: o melhor modo de lidar com o elemento servil naquela segunda metade do século. A preocupação em relação à mão de obra escravizada exposta naquela tarde de quarta-feira certamente mudou o conteúdo das conversas do fim de semana e chegou a tirar o sono de parte significativa dos legisladores imperiais. Parecia inequívoco a D. Pedro II que a emancipação era a via mais segura para a condução da política do império e ele foi enfático ao afirmar:

O elemento servil no império não pode deixar de merecer oportunamente a vossa consideração, provendo-se de modo que, respeitada a propriedade atual e sem abalo profundo em nossa primeira indústria, a agricultura, sejam atendidos os altos interesses que ligam à emancipação. Promover a colonização deve ser objeto de vossa particular solicitude. ${ }^{8}$

Nota-se que a emancipação do elemento servil se mostrava uma prioridade para a política imperial. Em meio a tantas dúvidas de como o processo deveria ser conduzido, os legisladores estavam certos de que tudo deveria ser calculado cuidadosamente para o bem da propriedade, priorizando a promoção da entrada de imigrantes que pudessem substituir gradativamente a mão de obra, garantindo que a agricultura, maior fonte de renda do Império, não fosse abalada.

A onda negra que seria lançada sobre a sociedade brasileira com a extinção do trabalho escravo foi a causa principal das dores de cabeça e do medo daqueles senhores e políticos. "O que fazer com os libertos?" parecia ser a pergunta que martelava na mente dos deputados após a fala 
do imperador. ${ }^{9} \mathrm{O}$ andamento das discussões e debates em torno da emancipação ratificam a existência de uma sociedade profundamente marcada pela heterogenia sociorracial: "uma minoria branca, rica e proprietária, e uma maioria não-branca, pobre e não-proprietária". ${ }^{10}$ Aliás, a propriedade foi o eixo em torno do qual giraram todas as decisões e direcionamentos referentes à questão do elemento servil.

O Projeto de Voto de Graças foi apresentado quatro dias depois da Fala do Trono:

A câmara dos deputados associa-se à ideia de oportuna e prudentemente considerar a questão servil no Império, como requerem a nossa civilização e verdadeiros interesses, respeitando-se, todavia, a propriedade atual, e sem abalo profundo na agricultura do país. Apoiar o governo de Vossa Majestade Imperial nas exigências da guerra com o Paraguai, nas urgentes medidas financeiras, nos desvelos pela colonização e instrução pública, na reforma da legislação relativa ao recrutamento, à justiça militar, ao quadro dos oficiais da armada, e à organização da guarda nacional, é dever de que a câmara dos deputados se acha compenetrada. ${ }^{11}$

Ao que parece, o Projeto de Voto de Graças apresentado na sessão de 27 de maio não contemplou os interesses, tampouco as expectativas dos parlamentares, boa parte deles latifundiários escravistas a quem a proposta de extinção do elemento servil certamente não agradara. O projeto de resposta à Fala do Trono foi discutido nas sessões de 4, 5, 7, 10, $12,14,15$ e 17 de junho daquele ano.

Com todo o ministério presente à sessão, foi em quatro de junho de 1867, na Segunda Parte da Ordem do Dia, que os parlamentares demonstraram suas primeiras impressões acerca da questão posta por Vossa Majestade. Sob olhares atentos e um profundo silêncio, Bernardo Avelino Gavião iniciou sua fala afirmando que a proposta de emancipação

9 Célia Maria Marinho de Azevedo, Onda negra, medo branco: o negro no imaginário das elites século XIX, Rio de Janeiro: Paz e Terra, 1987, p. 13.

10 Azevedo, Onda negra, medo branco, p. 36.

11 Brasil, Falas do Trono, p. 628. 
do trabalho escravo é "uma verdadeira proclamação de guerra social". ${ }^{12}$ Diante da instabilidade financeira da época que atingia principalmente a agricultura, a ideia de emancipação soou como uma incerteza para o futuro. ${ }^{13}$ Afinal, perguntava ele, "como se pretendia respeitar a propriedade atual e sem o abalo profundo na agricultura [quando] ergue-se essa ameaça indefinida contra tão vastos e importantíssimos interesses?". ${ }^{14}$ Foi, ainda, irônico ao afirmar a imprudência da proposta diante da instabilidade financeira da época, que atingia sobretudo a agricultura, "a grande fonte da receita pública e o principal elemento de nossa vida industrial". ${ }^{15}$ O bafafá, enfim, estava armado e se alongaria por algumas décadas após o fim da guerra contra o Paraguai, que recebeu diversos escravos comprados dos senhores pelas mãos do governo imperial. ${ }^{16}$

A insatisfação de Gavião Peixoto e outros deputados não surgiu do nada. Ele e muitos parlamentares sabiam das diversas experiências dos demais países do continente americano para pôr fim à escravidão, sendo a do Haiti a mais difícil de engolir, em que senhores e seus familiares soçobraram terrivelmente sob o ódio de escravos revoltados e sedentos por vingança e liberdade. Quantos daqueles negros, nas ruas ou nas casas, desejavam dar aos senhores brasileiros tratamento semelhante ao ocorrido em Carrancas, em 1833 ? $^{17}$

Aquela não foi a primeira vez que D. Pedro II defendia publicamente a liberdade do elemento servil na mesa de negociações rodeada por membros dos poderes Legislativo e Executivo. Nota-se, nos argumentos rancorosos de Gavião Peixoto, que a matéria envolvia interesses que poderiam gerar uma série de efeitos em cascata na economia e na própria sociedade brasileira. Não à toa, até o início da década de 1860 ,

12 Anais do Parlamento Brasileiro (RJ) - 1826 a 1873, Câmara dos Senhores Deputados, "Sessão de 22/05/1867", Tomo 2, p. 24, <http://memoria.bn.br/pdf/132489/per132489_1867_00002. pdf>, acessado em 08/07/2018.

13 Anais do Parlamento Brasileiro, "Sessão de 04/06/1867", op. cit., p. 24.

14 Anais do Parlamento Brasileiro, "Sessão de 22/05/1867", op. cit., p. 24.

15 Anais do Parlamento Brasileiro, "Sessão de 22/05/1867”, op. cit., p. 24.

16 Jorge Prata Sousa, Escravidão ou morte, Rio de Janeiro: Mauad, 1996; Álvaro Pereira do Nascimento, "Do cativeiro ao mar: escravos na Marinha de Guerra", Estudos Afro-Asiáticos, n. 38 (dez. 2000), pp. 85-112.

17 Marcos Ferreira de Andrade, “A pena de morte e a revolta dos escravos de Carrancas: a origem da 'lei nefanda' (10 de junho de 1835)", Tempo, v. 23, n. 2 (2017), pp. 264-289. 
como afirmou Ricardo Salles, "ninguém - ou muito poucos -, a não ser os próprios escravos, opunham-se efetivamente à escravidão". ${ }^{18}$ Saber que, nos Estados Unidos da América, a libertação dos escravizados rachou a nação pondo irmãos em exércitos opostos, matando mais de 600 mil pessoas, sendo a "mais custosa" na história daquele país, certamente gerou aflições no imperador e deve ter ocupado parte dos seus dias e noites em claro. ${ }^{19}$

Essas negociações foram alavancadas com o fim da guerra contra o Paraguai e a proximidade da libertação do ventre da mulher escrava. Segundo Tâmis Peixoto Parron, o ano de 1871, além de demarcar a imposição de um processo legislativo de emancipação da escravidão, revelou o desenrolar de uma "política da escravidão" caracterizada por uma rede de articulações entre os homens do capital e da política, defensores de uma estrutura "genuína e integralmente escravista". ${ }^{20}$

Em A politica da escravidão no império do Brasil, Tâmis Parron lembrou que o pós-1850 representou o fim de uma era, com a supressão do contrabando negreiro. Os impactos na economia nacional e na dinâmica das plantations, com o aumento dos preços dos cativos, a tendência inflacionária dos alimentos e a estrutura do tráfico provincial, deram um tom diferenciado às relações entre senhores e escravos, bem como entre políticos e proprietários.

O que se evidencia é que, além dos desafios econômicos, eventos internacionais interferiram na reflexão parlamentar sobre a escravidão, especialmente sobre propostas para sua manutenção e fortalecimento em meio às estratégias para a substituição gradual do elemento servil pelo colono. Nesse período, as relações escravistas se reformularam a partir dos processos históricos da economia capitalista mundial, de modo que fica evidente que a oposição entre capitalismo e escravidão deve ser repensada. Compreende-se aqui que a industrialização não enfraqueceu a escravidão, e o dito século antiescravagista acabou por denotar o

18 Ricardo Salles, E o Vale era o escravo, Rio de Janeiro: Civilização Brasileira, 2008, p. 89.

19 Leandro Karnal, Marcus Vinícius de Morais, Luiz Estevam Fernandes e Sean Purdy, História dos Estados Unidos: das origens ao século XXI, São Paulo: Contexto, 2007, p. 136.

20 Tâmis Peixoto Parron, A política da escravidão no Império do Brasil, 1826-1865, Rio de Janeiro: Civilização Brasileira, 2011, p. 12. 
apogeu do seu desenvolvimento. Como salientou Parron, "na aurora do capitalismo industrial, porém, entre 1780 e 1815, todo esse sistema foi redesenhado, de maneira que as sociedades escravistas apresentaram não apenas incrementos quantitativos, mas também saltos qualitativos radicais". ${ }^{21}$

Os resultados desse processo podem ser observados também no que tange às relações entre senhores e escravizados. A proposta lançada pelo imperador e "a consideração" pela questão servil anunciavam a quebra da hegemonia da classe senhorial local. Para Chalhoub, "a falência de certa política de domínio" também permeou o debate em torno da emancipação, já que a partir dali o Estado passaria a interferir numa relação que se entendia protagonizada pelos senhores e possuidores de trabalhadores escravizados. ${ }^{22}$

Propriedade, trabalho, falência, domínio, crise, revoltas e violência são palavras que pautaram os debates realizados entre os contemporâneos do século XIX e foram analisadas pela historiografia apresentada. Além da expectativa dos produtores em relação à economia, havia o enorme temor, especialmente dentre a população livre mais abastada que vivia em cidades, como a Corte. ${ }^{23}$ Com aproximadamente cem mil escravos em 1864, o Rio de Janeiro fervilhava nos embates entre livres, libertos e escravos. ${ }^{24}$ Sendo a cidade capital da Monarquia, ali estavam intelectuais, ricos proprietários de terras e escravizados, profissionais liberais e toda a gente dos ministérios, Câmara, Senado e departamentos de governo.

Do Parlamento às ruas, analisar as opiniões impressas acerca do horizonte de expectativas que se desenhou em torno da questão servil é fundamental para compreender o cenário que definiu os rumos da emancipação. Assim, o olhar está voltado para a opinião de pessoas que já davam como certo e próximo o fim do sistema escravista e indicaram alternativas, formas de conduta e hábitos que permitissem uma relação mais amigável com os futuros emancipados.

21 Parron, A política da escravidão, p. 26.

22 Sidney Chalhoub, Visões da liberdade, São Paulo: Companhia das Letras, 1990, p. 90.

23 Azevedo, Onda negra, medo branco.

24 Robert Conrad, Os últimos anos da escravatura no Brasil, Rio de Janeiro: Civilização Brasileira, 1975, p. 346. 
Medo dos efeitos da emancipação, propostas para a manutenção do poder senhorial sobre libertos, reação dos proprietários a uma possível abolição orquestrada pelo Estado... nada disso era novidade na sociedade imperial brasileira. A "onda negra" que ocupou o imaginário das elites no processo da emancipação desaguou como um tsunami sobre os políticos do império, mas começou a se formar bem antes daquela Fala do Trono. Célia Maria Marinho de Azevedo revelou inquietações e projetos de emancipação elaborados por João Severiano Maciel da Costa, Antônio Velloso de Oliveira, José Bonifácio, José Eloy Pessoa da Silva, Frederico Leopoldo Cezar Burlamaqui e Domingos Alves Branco Moniz Barreto, antes mesmo do fim do comércio Atlântico, e por vários outros homens letrados, políticos, cientistas e religiosos, já na segunda metade do XIX. ${ }^{25}$

Ao que parece, o século da emancipação trouxe transformações e permanências. Se por um lado revelou a nova face da escravidão, por outro, acentuou o antigo medo, velho conhecido dos senhores. Nessa perspectiva, estão aqui expostas linhas cujos autores trazem perfis heterogêneos, desde a escrita de um engenheiro civil e de um político, com o intuito de instruir fazendeiros a manter a mão de obra sob controle como Antônio da Silva Netto, em 1866, e Adolfo Bezerra de Menezes, em 1869 -, bem como os planos de uma parteira e de um advogado progressista influenciado pelo abolicionismo norte-americano - Madame Durocher e Theodore Parker, respectivamente, que em 1871 publicaram suas impressões e propuseram direcionamentos diante de tema tão oportuno à época.

\section{Como pensam sobre o elemento servil}

Quando procurou a Typographia Perseverança, à rua do Hospício, na Corte, para publicar seus Estudos sobre a emancipação dos escravos no Brasil, Antônio da Silva Netto estava determinado a "oferecer" aos "senhores fazendeiros" suas reflexões para um "futuro" sem escravidão.

25 Para uma análise dos projetos de emancipação na primeira metade do século XIX, cf. Azevedo, Onda negra, medo branco. 
Era necessário avisar "a humanidade, para que ela se acautele com o tempo", antes do "perigo iminente". ${ }^{26}$

Antônio da Silva Netto era um engenheiro civil baiano formado pela Escola Militar. ${ }^{27}$ Talvez essa formação tenha lhe dado os conhecimentos com os quais também se intitulava "bacharel em Matemática e Ciências Físicas". Os dados levantados permitem cogitar que vivia de ofícios liberais e procurava estar sempre em associações fundamentais para se inserir entre os homens de poder na época - a exemplo de tornar-se membro do Conselho Administrativo da famosa e relevante Sociedade Auxiliadora da Indústria Nacional, ${ }^{28}$ na Seção para Melhoria das Raças Animais. ${ }^{29}$

Embora abolicionista e republicano, ${ }^{30}$ autodeclarava-se senhor de escravos e dizia abertamente em sua obra que o crime da escravidão existia em sua casa, na casa dos seus vizinhos e por todas as casas do Brasil. ${ }^{31}$ Segundo Blake, nos anos que se seguiram à publicação do opúsculo aqui analisado, Silva Netto escreveu outras duas obras que versavam acerca da emancipação da mão de obra escravizada - A coroa e a emancipação do elemento servil e Segundos estudos sobre a emancipação dos escravos.

26 Antônio da Silva Netto, Estudos sobre a emancipação dos escravos no Brasil, Rio de Janeiro: Typographia Perseverança, 1866, p. 3. <http://www2.senado.leg.br/bdsf/handle/id/174449>, acessado em 24/07/2018.

27 Silva Netto foi preterido num concurso para provimento da cadeira de Matemática do Instituto Comercial da Corte, no qual estudou o pai de Lima Barreto (Lília Moritz Schwarcz, Lima Barreto: triste visionário, São Paulo: Companhia das Letras, 2017, pp. 43-44), e foi aos jornais reclamar do processo desqualificando seus colegas (Diário do Rio de Janeiro, 30 out. 1863, pp. 2-3, "Instituto Comercial", fl. 2-3, Hemeroteca Biblioteca Nacional - BNDigital, $<$ http://memoria.bn.br/pdf/094170/per094170_1863_00297.pdf>, acessado em 10/12/2018). Cf. Augusto Victorino Alves Sacramento Blake, Diccionario Bibliographico Brasileiro, Rio de Janeiro: Typographia Nacional, 1883, v. 1, pp. 316-317, <http://www2.senado.leg.br/bdsf/ handle/id/221681>, acessado em 10/12/2018.

28 Rafael de Bivar Marquese e Tâmis Peixoto Parron, "Internacional escravista: a política da Segunda Escravidão”, Topoi, v. 12, n. 23 (2011), p. 96, <http://www.scielo.br/pdf/topoi/ v12n23/1518-3319-topoi-12-23-00097.pdf>, acessado em 20/07/2018.

29 O Auxiliador da Indústria Nacional, Rio de Janeiro: Typographia de N. Lobo Vianna \& Filhos, 1863, fl. 1, Hemeroteca Biblioteca Nacional (BNDigital), <http://memoria.bn.br/docreader/ DocReader.aspx?bib=302295\&pagfis $=24518>$, acessado em 05/03/2019.

30 Fabiano Dauwe, "A libertação gradual e a saída viável. Os múltiplos sentidos de liberdade pelo fundo de emancipação de escravos" (Dissertação de Mestrado, Universidade Federal Fluminense, 2004), p. 41.

31 Silva Netto, Estudos sobre a emancipação dos escravos no Brasil, p. 31. 
O processo de emancipação o impactava diretamente, a ponto de elaborar projetos e alertar aos demais proprietários sobre os melhores meios de conduzir a libertação da mão de obra escravizada. ${ }^{32}$

Ao longo de 48 páginas, afirmou não ser tarefa difícil comprovar a necessidade e a viabilidade da emancipação. Para isso, realizou estudos sobre a condução da Inglaterra e da França no processo de emancipação - não à toa, os países mantenedores do trabalho de escravizados em boa parte das Américas. Por meio de diversos cálculos matemáticos, documentos oficiais e pensadores abolicionistas, procurou mostrar que o pagamento de indenização aos proprietários só serviu para "agravar as finanças" daqueles países. ${ }^{33}$ Requentando propostas contemporâneas no Brasil e noutros países escravistas, também indicava uma redefinição das relações sociais mantidas entre senhores e escravos. Se seus colegas desejavam utilizar essa mudança para assegurar a escravidão ou esticá-la ao máximo de tempo possível, ${ }^{34}$ sua maior contribuição foi dizer aos fazendeiros que essa mudança não ajudaria a manter a paz na sociedade brasileira. Para ele, a redefinição das relações seria fundamental para, gradualmente, serem construídos novos laços de parceria entre as partes e garantir a produção nas diversas atividades laborais logo após a emancipação dos escravizados que se avizinhava.

Para isso, Silva Netto apelou aos jornalistas uma parceria, no intuito de conscientizar - ou melhor, "doutrinar" - os senhores a fim de viabilizar esse olhar humanitário em relação aos cativos.

Se os jornalistas tomassem por obrigação doutrinar os possuidores de escravo, mostrando-lhes as vantagens futuras em seguirem uma conduta humanitária em relação aos seus escravos, alcançariam maior resultado que todas as leis preventivas. É da obrigação dos

32 Blake, Diccionario Bibliographico Brasileiro, p. 317.

33 Silva Netto, Estudos sobre a emancipação dos escravos no Brasil, p. 28.

34 Cf. Rafael de Bivar Marquese, "A administração do trabalho escravo nos manuais de fazendeiro do Brasil Império, 1830-1847”, Revista de História, n. 137 (1997), p. 96, <http://www.revistas. usp.br/revhistoria/article/view/18829/20892>, acessado em 05/03/2019; e Salles, E o Vale era o escravo, p. 247. 
que tomam parte no movimento das sociedades modernas multiplicar os dados cronológicos para a história do progresso. ${ }^{35}$

Para além de um discurso moralizante, a proposta de Silva Netto se vinculava à intenção de manter a autonomia senhorial na condução do projeto emancipacionista. Falando aos seus pares, afirmou: "é uma questão que nos afeta como agricultores". ${ }^{36}$ Desse modo, urgia que fosse definida e direcionada pelos senhores, não pelo Estado:

Pode hoje o agricultor descansando das fadigas da roça adormecer acreditando que amanhã levará como de costume os seus escravos ao trabalho, e amanhecer no meio de pretos emancipados. Abraçando, portanto, o fato como inevitável, é necessário que nós desde já nos preparemos para receber a emancipação que nos bate à porta. ${ }^{37}$

Nesse sentido, a prerrogativa central da série de conselhos dados aos fazendeiros consistia numa reorganização das relações mantidas com a escravaria, que partia, principalmente, da abolição dos castigos físicos e atribuição de "castigos morais", temendo, inclusive, uma reação em cadeia dos pretos recém-emancipados.

Tratem de se preparar, modifiquem seus instintos selvagens, substituam suas fórmulas automáticas pelas fórmulas dos seres pensantes, procurem fazer dos seus escravos de hoje amigos de amanhã, porém, amigos morigerados; porque, a emancipação mais ou menos cedo há de vir, e os filhos recentemente vendidos pelos pais, os irmãos pelos irmãos, terão ocasião de se porem em pé ainda ensanguentados pelos ferros do cativeiro e perguntarem - com que direito ontem nos vendestes? ${ }^{38}$

Denunciando a violência empregada por esses senhores ao longo dos anos de escravismo - inclusive aquela praticada por eles em relação

35 Silva Netto, Estudos sobre a emancipação dos escravos no Brasil, p. 28.

36 Silva Netto, Estudos sobre a emancipação dos escravos no Brasil, p. 33.

37 Silva Netto, Estudos sobre a emancipação dos escravos no Brasil, p. 34.

38 Silva Netto, Estudos sobre a emancipação dos escravos no Brasil, pp. 36-37. 
às mulheres escravizadas, que viviam em "concubinato imundo"-, Silva Netto recorre ao temor de insurreições para convencê-los da necessidade de repensar as relações como um caminho possível para a manutenção da oferta de mão de obra para a lavoura.

Segundo o manual proposto por Silva Netto, a escravidão no Brasil poderia ser extinta gradualmente em vinte anos, libertando os recém-nascidos de cor (seriam criados por suas mães) e os escravizados conservados por cinco anos nas capitais provinciais e na Corte, e dez anos nas outras cidades e vilas do Império. Além desses, todos aqueles empregados na lavoura no fim de vinte anos, "completando assim a emancipação geral, sem indenização alguma do Estado aos proprietários". ${ }^{39}$

Em linhas gerais, a emancipação pensada por Antônio da Silva Neto propunha a manutenção do poder dos senhores sobre a libertação dos seus cativos, o que consequentemente garantira a autonomia de sua propriedade, retirando do Estado o poder de direcionar e/ou impor os mecanismos que conduziriam à extinção da mão de obra escrava no Brasil.

Três anos após a publicação do livro de Silva Netto, foi publicado o opúsculo A escravidão no Brasil e as medidas que convêm tomar para extingui-la sem dano para a nação, de Adolpho Bezerra de Menezes. ${ }^{40}$ Médico, militar, jornalista, vereador por várias legislaturas e deputado, o cearense Bezerra de Menezes, ${ }^{41}$ nascido em 1831, escreveu livros e teve atuação intensa no século XIX - muito embora seja mais conhecido pelo universo espírita, que o consagrou no século XX como o "médico dos pobres". ${ }^{42}$

Tal qual Silva Netto, Bezerra de Menezes assumiu uma fala reta e se posicionou severamente avesso às "raízes malditas do cancro da

39 Silva Netto, Estudos sobre a emancipação dos escravos no Brasil, p. 43.

40 Adolfo Bezerra de Menezes, A escravidão no Brasil e as medidas que convêm tomar para extingui-la sem dano para a nação, Rio de Janeiro: Typographia Progresso, 1869, <https:// digital.bbm.usp.br/handle/bbm/4782>, acesso em 08/07/2018.

41 Blake, Diccionario Bibliographico Brasileiro, p. 9.

42 Bezerra de Menezes figura a lista dos "vereadores que fizeram história" no site da Câmara Municipal do Rio de Janeiro, ao lado de Pedro Ernesto, Barão de Itacaré e Ary Barroso. Em sua descrição, é lembrado como um político e jornalista dedicado a defender a "emancipação dos escravos" e como o "médico dos pobres". Cf. Câmara Municipal do Rio de Janeiro, "Vereadores que fizeram história", Bezerra de Menezes, <http://www.camara.rj.gov.br/historia_bezerramenezes.php?m1=acamrio\&m2=historia_camara $>$, acessado em 05/03/2019. 
escravidão". ${ }^{43}$ Embora fosse apoiador dos ideais franceses de 1789, parece ter se limitado à defesa da igualdade jurídica entre os homens, já que, para ele, os trabalhadores escravizados representavam uma "lamentável aberração do espírito humano", condenados à "perdição eterna pelos instintos brutais que borbulham em todo o espirito". ${ }^{44}$

Embora tenha dialogado em algumas questões com a escrita do contemporâneo Silva Netto, principalmente no tocante à condenação da violência física e ao tom desumanizador das relações entre senhores e escravos, Bezerra de Menezes desenhou uma narrativa recheada de preocupações morais em relação ao futuro diante das atitudes e comportamentos dos escravizados.

O perigo de possíveis revoltas, de insurreições e da convivência e disseminação de uma cultura perniciosa, própria de uma gente violenta e prostituída, mostrava-se um desassossego para Bezerra de Menezes. Muito preocupado com o bem-estar das boas famílias e com a moral das crianças, trouxe uma narrativa sobrecarregada de adjetivações desqualificadoras em relação às populações negras escravizadas. Segundo ele, extinguir a escravidão era o caminho para a salvação moral da pátria.

Pode haver paz e felicidade para as famílias, enquanto guardarem elas em seu seio essa cratera ardente que lhes requeima sempre a flor da inocência e da virtude de seus filhos?

Pode haver esperança de futuro para uma nação, onde a família está irremediavelmente condenada a tão desgraçada condição? ${ }^{45}$

Defensor do trabalho livre, Menezes recorreu à experiência vivenciada pelos escravistas cearenses para ratificar sua tese de que sem escravos se vive melhor e mais feliz. Numa referência à Fala do Trono de 1867, foi cético em relação aos reais interesses do Império na condução da questão servil, condenando a interferência do Estado no assunto e as boas intenções dos ministros em debaterem a questão. Para ele, tratava-se de uma decisão a ser tomada pelos cidadãos, a fim de tirar o Brasil

45 Menezes, A escravidão no Brasil, p. 13. 
da situação em que se encontrava, pelo bem da indústria, da moral, da família e dos bons costumes.

Seus créditos de nação civilizada e cristã; o interesse de sua indústria; a segurança e o bem-estar da família brasileira; e, sobretudo a necessidade de uma educação doméstica sã, dessa educação que é o mais firme alicerce de uma sociedade; tudo reclama instantemente a redenção de uma raça inteira, condenada por seus irmãos a uma eterna degradação moral. ${ }^{46}$

De que modo, então, levaria a efeito a grande reforma que propunha? A princípio, Adolfo Bezerra de Menezes afirmou que qualquer projeto de emancipação deveria atentar para a proteção da propriedade privada e para o bem comum, o que, de fato, não parece um discurso inovador nem mesmo àquela época. O diferencial da proposta de Menezes residiu na crítica que fez aos modelos pensados para a emancipação. Sobre as propostas de abolição imediata/indenizatória ou agendada/ gratuita, julgou que nenhuma delas respeitava o direito de propriedade em sua plenitude, já que a primeira tiraria do proprietário o direito de estimativa de propriedade, e a segunda o ofenderia de frente e muito abertamente, por negar-lhe o ressarcimento do valor investido. Sobre os interesses gerais da nação, afirmou:

Em relação ao interesse geral, nenhum dos dois merece o apoio sensato; visto como tanto um quanto outro atiram, de chofre, no seio da sociedade, com os direitos de cidadão brasileiro, toda essa massa de homens criados e educados para escravos; sem princípios de honra, de justiça, de dever; verdadeiros animais selvagens, dominados dos mais perigosos instintos. ${ }^{47}$

Acerca da emancipação gradual, via esses projetos como mais vantajosos para os senhores, uma vez que a garantia da indenização das crias compradas por entidades filantrópicas ou das mulheres escravas seria equivalente ao investimento naquele tipo de peça, muito mais

46 Menezes, A escravidão no Brasil, p. 18.

47 Menezes, A escravidão no Brasil, p. 21. 
barata nos mercados do império. Nessa altura da escrita, posicionou-se favorável e sem ressalvas à ideia de uma lei de libertação do ventre da escrava, por considerar mais vantajoso economicamente para os proprietários. Ademais, para ele, o filho da escrava era concebido como um ser não corrompido pela conduta nefasta dos escravos, portanto passível de ser educado e adequado ao convívio social.

Estabelecer regras de convívio com fins de regeneração moral da raça foi, aliás, o grande mote da proposta de Bezerra de Menezes. Aos escravos embrutecidos pelo tempo de cativeiro, Menezes não via horizonte senão a morte libertadora, que não tardaria a chegar: "pelos cálculos da duração da vida humana, aplicados a suas condições especiais de existência e às condições especiais do país em que vive, em rigor terá desaparecido no prazo de 25 anos, levando consigo os últimos vestígios da escravidão no império". 48

Aos libertos pelo ventre, vislumbrou uma criação distante da influência das mães e direcionada pelo Estado, como se órfãos fossem, a ser realizada em casas de criação sob responsabilidade das municipalidades. Acerca da educação, como considerava os libertos inaptos para as carreiras literária ou científica, seu processo educacional deveria ser restrito à instrução primária, aos princípios morais e religiosos. Passado o período da instrução primária, os rapazes aprenderiam noções de artes mecânicas, e as raparigas, os afazeres domésticos. ${ }^{49}$

As linhas escritas por Bezerra de Menezes traçam as estratégias para conduzir à extinção a escravidão no Brasil. O destino dos cativos é incerto e duvidoso se levados em conta seus propósitos de eliminação da suposta imoralidade da raça negra e a extirpação do elemento servil do seio das boas famílias do Império. Para ele, é evidente que a defesa da família e dos bons costumes sobrepõe à da propriedade, daí sua satisfação em "haver concorrido indiretamente para a mais importante reforma de que precisa o Brasil."

49 Menezes, A escravidão no Brasil, p. 24.

50 Menezes, A escravidão no Brasil, p. 40. 
O terceiro livro analisado foi escrito pelo advogado Luiz Barbosa da Silva e utilizava o pseudônimo de Theodoro Parker. ${ }^{51}$ No panfleto publicado em 1871, Elemento servil, é visível a perspectiva republicana de Parker acerca do cativeiro. ${ }^{52}$ Ao que parece, a questão servil havia muito o inquietava, de modo que assumira o pseudônimo de um abolicionista norte-americano. Tudo indica ter sido ele um dos redatores do jornal A Actualidade: Jornal da Tarde (entre 1858 e 1864) e do periódico A República (entre 1871 e 1872) que, inclusive, trazia uma seção intitulada "Parlamento", em que as discussões realizadas na Câmara e no Senado eram comentadas pelos cronistas do jornal..$^{53}$ Entre os debates, o mais acalorado se deu em torno da emancipação do elemento servil.

Para Parker, a escravidão era mais danosa aos senhores que aos próprios cativos, principalmente numa perspectiva econômica. Conforme salientou Fabiano Dauwe, ${ }^{54}$ impelidos a trabalhar por seu sustento, seriam muito mais produtivos. Para ele, a reconfiguração nas relações de trabalho a partir da emancipação traria outros benefícios econômicos, com o aumento do número de trabalhadores disponíveis: "Emancipados os negros, não permanecem as nossas terras íntegras em toda a sua fecundidade? Não ficam no país todos esses trabalhadores de cor, que existem hoje, e não entram para o trabalho todos os que até aqui viviam à custa dele e que agora teriam que viver à sua própria custa?". ${ }^{55}$

Parker assegurou a insustentabilidade do regime escravista e disse que a emancipação não traria nenhum mal, levando em conta que, aos seus olhos, essa mão de obra seria utilizada em novos moldes. Sob o

51 As referências a esta obra serão feitas em nome de Theodore Parker, seguindo a prerrogativa do autor. "Sob o pseudônimo de um religioso norte-americano conhecido por seu radicalismo abolicionista, Luiz Barbosa da Silva, natural de Bananal (SP), compôs esse panfleto no contexto dos debates parlamentares em torno do ventre livre (1871)." Cf. Theodore Parker, "Elemento Servil, <https://www2.senado.leg.br/bdsf/handle/id/174445>, acessado em 08/07/2018.

52 Parker, "Elemento Servil".

53 Camila Pereira Martins, "Republicanismos: Rio de Janeiro e Lisboa (1870-1891)" (Dissertação de Mestrado, Universidade Federal de Juiz de Fora, 2015), pp. 39-40.

54 Fabiano Dauwe, "Abra os olhos o nosso governo: a trajetória dos intelectuais republicanos abolicionistas na discussão da Lei do Ventre Livre", Anais do XXIX Simpósio Nacional de História (Brasília, 2017), p. 15, <http://www.snh2017.anpuh.org/resources/anais/54/1502847644_ARQUIVO_ABRAOSOLHOSONOSSOGOVERNO-Versaoparaenvio.pdf>, acessado em 11/05/2018.

55 Parker, "Elemento Servil”, p. 16. 
ponto de vista econômico, criticou a proposta da Lei do Ventre Livre, afirmando: "O governo parecendo abolicionista não o é absolutamente, antes é o representante de vontades postas a soldo de uma causa que defendem sem conhecer, sem amar e sem compreender". ${ }^{56}$ Segundo ele, os resultados seriam muito mais proveitosos se libertassem não o ventre da escrava, mas todas as mulheres que tivessem em vias de serem mães, ou que já o fossem.

A respeito da legalidade da escravidão, condenou sua prática e, mais ainda, sua hereditariedade. Além disso, reuniu em seu escrito ideias centrais do discurso republicano: demonstrou os efeitos nocivos da escravidão, em especial à racionalidade econômica e ao Direito, propôs a libertação de todas as mulheres cativas em idade fértil e se mostrou contrário à indenização aos senhores. Segundo Dauwe,

[...] sua publicação nas páginas de um jornal de grande circulação, e posterior edição em volume anunciado pelo mesmo jornal, demonstra o interesse do grupo de republicanos ligado ao jornal no "encaminhamento da questão servil", e os esforços que despendiam para interferir na opinião pública a respeito. ${ }^{57}$

Nesse rastro, a consulta às Atas das Sessões Parlamentares e aos livretos e manuais publicados no âmbito dos debates sobre a emancipação do elemento servil no Império permite refletir acerca dos caminhos da abolição nesse cenário político imperial. Claro que esse é um painel preliminar, todavia fica evidente que o projeto de extinção da mão de obra escravizada foi pensado a passos lentos pelo Estado e esteve intrinsecamente relacionado a uma proposta de proteção das fortunas e propriedades dos senhores e possuidores de escravos no Império do Brasil.

Caminhando para o encerramento dessas reflexões, cabe o retorno ao escrito de Madame Durocher, a Maria Josephine Mathilde Durocher. Filha de uma costureira francesa envolvida na Revolução de 1789, Durocher chegou ao Brasil ainda muito pequena. Aqui aprendeu o ofício na "Faculdade de Medicina do Rio de Janeiro", tornando-se parteira da

56 Parker, "Elemento Servil", p. 31.

57 Dauwe, "Abra os olhos o nosso governo", p. 17. 
Casa Imperial e membro honorário da Academia Imperial de Medicina do Rio de Janeiro. ${ }^{58}$

Por sua criação materna, dizia ela ter horror à escravidão. Tão convicta desse mal, procurou encontrar a melhor forma de pôr fim àquelas vexaminosas cenas. O processo, no entanto, deveria ser gradual. Para ela, deveria evitar-se qualquer medida açodada, que levaria à "queda completa da lavoura" além de trazer "assassinatos por vingança contra seus antigos senhores". Em resumo, "crimes para as quais não haverá tribunais suficientes, nem polícia bastante numerosa e enérgica para conter as desordens". ${ }^{59}$

Mas como fazê-lo? Madame Durocher parecia ter grande conhecimento de experiências internacionais por ser leitora e autora de uma tese de medicina. Sob o título Ideias por coordenar a respeito da emancipação, sugeriu a criação de um "código" a ser seguido por fazendeiros e escravos na lida das lavouras, que passariam a ser chamados de "superiores" e "subordinados", abandonando as "aviltantes" denominações às quais eram referenciados. Por meio desse repositório simples de lei, os primeiros conheceriam os "limites de sua autoridade", e os segundos, "seus direitos e seus deveres". Nesse pequeno código, redigido por um "legislador", estavam os segredos que poderiam acalmar a ansiedade da nobre parteira:

[...] será declarado a ração e gênero de comida e vestuário de verão e de inverno, os dias e horas de trabalho no verão ou no inverno, as horas de refeição, o tempo concedido para elas, as horas do recolher e do despertar para o trabalho no inverno como no verão, os castigos infringidos a tal ou tal falta em seus deveres, à falta de subordinação ou falta de respeito a seu superior ou a seu delegado ou representante; as permissões de saída, a observância do descanso nos domingos e a obrigação de ouvir missa e uma prática religiosa e moral do capelão, a confissão anual. ${ }^{60}$

58 Durocher, Ideias por coordenar, p. 2.

59 Durocher, Ideias por coordenar, p. 5.

60 Durocher, Ideias por coordenar, p. 10. 
Em nenhum momento de seu texto a parteira fez referência a qualquer possibilidade de remuneração aos futuros emancipados. Ou seja, sua proposta defendia a manutenção das relações de trabalho escravistas sob nova nomenclatura, que seguiria um código mais bem definido que as convenções existentes até aquele momento. Essa mudança seria o suficiente, em seus cálculos, para ambas as partes aprenderem a construir uma nova sociedade, na qual os "subordinados" saberiam viver em liberdade e sem o sabor da vingança, e os "superiores" teriam a mão de obra garantida, desde que reconhecessem seus limites e tratassem melhor seus subordinados, fosse durante o frio do inverno ou no calor do verão. Até castigos poderiam aplicar naqueles antes denominados escravos. Essas experiências estabeleceriam formas diferentes de relações de trabalho análogas à escravidão, que já eram tentadas na África francesa e em outras regiões de dominação europeia. ${ }^{61}$

Ela pensava também na indenização aos senhores pelos escravos libertos, uma das maiores discussões sobre o assunto durante a segunda metade daquele século. Deveriam todos, independentemente da nacionalidade, contribuir com um "imposto filantrópico" capaz de "resgatar um ou mais subordinados" (escravos) a cada dia sete de setembro, durante a comemoração do dia da independência. Finalmente, os "subordinados" poderiam trabalhar sob ordens de outros "superiores".

Novamente, Durocher deve ter consultado o dicionário em sua estante e encontrado uma denominação que substituía "venda de escravo" por "transpasse de inferior" pelo preço convencionado entre os contratantes. Seria, ainda segundo ela, "o meio de acabar o aviltamento da venda de carne humana sem lesar o interesse pecuniário. Entendemos que a venda do homem é tão aviltante para o vendido como para o vendedor e o comprador". ${ }^{2}$

De "venda" para "transpasse" percebe-se uma proposta pautada num perfil extremamente conservador para formar cidadãos primeiro e,

61 Cf. Frederick Cooper, "Condições análogas à escravidão", in Frederick Cooper, Thomas Holt e Rebecca Scott (orgs.), Além da escravidão, Rio de Janeiro: Civilização Brasileira, 2005, p. 221; e Paul Lovejoy, A escravidão na África, Rio de Janeiro: Civilização Brasileira, 2002, pp. 328-329.

62 Durocher, Ideias por coordenar, p. 19. 
assim, abolir a escravidão. Venda de pessoas, castigos corporais, aulas de disciplinas escolares e religião com maior sensibilidade do senhor para com o escravo, ou melhor, do "superior" para o "subordinado" - eis a receita de Durocher para a emancipação gradual da escravidão!

Ela e boa parte desses formuladores enfrentavam o dilema acerca das relações de trabalho que deveriam imperar dali em diante, assim como ocorrera em boa parte do mundo após a condenação da escravização moderna de africanos e africanas. Trabalho livre, compulsório, análogo à escravidão? Essas dúvidas permaneceram no século XX e persistem nos dias atuais. Infelizmente, não é incomum, no conforto dos sofás das nossas salas, que a imprensa nos surpreenda com notícias de exploração ou libertação de trabalhadores em condições análogas à escravidão. Há fazendeiros, empresários de pequenas ou de empresas transnacionais que ainda pensam como a parteira Durocher, mas também agem, exploram trabalhadores(as) e geram riqueza para seus próprios bolsos nos mais diferentes espaços deste mundo, mesmo que tenham de enfrentar a enfadonha fiscalização de organismos nacionais e internacionais de controle. ${ }^{63}$

\section{Considerações finais}

As expectativas quanto ao futuro podem ser torturantes. "O que será o amanhã?" não é uma questão somente da atualidade. Ela corrói faz tempo. Até o início dos anos $1860,{ }^{64}$ os livres ao menos sabiam da viabilidade da extinção do tráfico ilegal de escravos, que a polícia vez ou outra combatia, mas ainda havia fazendas abastecidas clandestinamente com africanos. A força da escravidão, como nos ensinou Chalhoub, ${ }^{65}$ era cada vez mais agressiva.

Notícias sobre a abolição de escravos nas Américas eram ouvidas, mas nada que realmente tirasse o sono dos brancos livres e bem

63 International Labor Organization, "P029: Protocol of 2014 to the Forced Labour Convention, 1930", <https://www.ilo.org/dyn/normlex/en/f?p=NORMLEXPUB:12100:0::NO::P12100_ INSTRUMENT_ID:3174672\#A1>, acessado em 15/11/2018.

64 Daniela Paiva Yabeta de Moraes, "A capital do Comendador: a Auditoria Geral da Marinha no julgamento sobre a liberdade dos africanos apreendidos na Ilha da Marambaia (1851)" (Dissertação de Mestrado, Universidade Federal do Estado do Rio de Janeiro, 2009).

65 Sidney Chalhoub, A força da escravidão, São Paulo: Companhia das Letras, 2012, p. 35. 
aquinhoados. Acomodavam-se em suas camas, arrumavam seus travesseiros e dormiam no silêncio das noites oitocentistas.

Os produtores passaram a debater formas de manter a quantidade de escravizados necessária ao trabalho em suas lavouras, mesmo sem a entrada legal ou ilegal de africanos. Reflexo disso foi sentido quando se tornaram "porta-vozes das classes proprietárias de certas regiões do país", publicando manuais nos quais propunham uma "teoria sobre a administração dos escravos". Como afirmou Rafael Marquese, tratava-se de reservar "melhorias no sustento material dos cativos, cessão de espaços de lazer, o cultivo de roças, estímulo à formação de famílias e o cuidado com os recém-nascidos". ${ }^{66}$ Outros, segundo Ricardo Salles, tentaram seguir essas teorias e incentivaram a "reprodução natural" dos escravizados, na esperança de suprir as vagas abertas pela extinção do comércio de africanos. ${ }^{67}$ Mas ainda não se preocupavam fortemente com a iminência da emancipação do cativo.

Aquelas Falas do Trono e o movimento do imperador nos bastidores do Império, na década de 1860, começaram a tirar o sono dos produtores e a pôr o debate da emancipação servil no cotidiano daquelas mesmas pessoas. A coisa piorou ainda mais ao verem o governo se meter num espaço crucial, entre proprietário e propriedade, com a Lei do Ventre Livre. ${ }^{68}$ A emancipação gradual da escravidão dava seus passos mais firmes e duros na instituição.

Ora, o que seria do cotidiano das pessoas livres sem escravizados a trabalhar? Muita gente começou a se revirar mais na cama naquelas noites. Antes, havia certezas para aquela sociedade. Senhores corrigiam disciplinarmente o/a atrevido/a que ousou sair do seu lugar de subalternidade. Mas, se extintos os poderes do senhor, enfim, a quem reclamar? Não haveria mais donos daquela turba de pessoas negras ainda em vultoso número na década de 1860.

Além disso, duvidavam que aquelas pessoas escravizadas tivessem condições de ser como eles e elas. Faltavam-lhes os substratos

66 Rafael Marquese, Feitores do corpo, missionários da mente. Senhores, letrados e o controle dos escravos as Américas, São Paulo: Companhia das Letras, 2004, p. 297.

67 Salles, E o Vale era o escravo, p. 252.

68 Chalhoub, Visões da liberdade, pp. 158-161. 
civilizacionais para viverem em liberdade; os costumes e valores europeus em relação ao trabalho e ao comportamento disciplinado dos seus corpos e falas em todas as ações sociais. Propor alguma solução em um livreto, um manual ou pagando algum espaço em jornais eram caminhos para expor seus temores nas expectativas quanto ao futuro. Uma ansiedade para aquela gente livre e abastada que temia guerras, roubos, assassinatos e revoltas de escravizados.

Definir o lugar do liberto na sociedade brasileira se tornou necessidade por ser uma forma de proteção contra os próprios medos existentes entre os grupos livres, que até a metade do século XIX tinham seus privilégios bem definidos e pouco acessíveis aos demais grupos. Reconheciam o resultado da sua própria obra, desenhada nas cores vivas do incômodo guardado por escravizados e escravizadas, subtraídos de suas liberdades, a dor de quem fora sequestrado das costas africanas e vendido no Brasil, o sentimento de vingança pelo castigo físico sofrido, a falta que um ente querido fazia após ser vendido para longe, a obrigação da subserviência diante do branco, perceptível na forma como se havia de abrir caminho para ele, sem encará-lo ou dirigir-lhe a palavra em voz baixa. Certamente, ao pesarem toda essa realidade em relação ao outro, ao indivíduo outrora escravizado, aquela gente livre, de elite ou que mantinha relações próximas a ela garantindo seus lugares privilegiados, percebiam a importância de se manterem assim para demarcarem seu espaço de poder e rejubilavam-se pelo status alcançado, como bem representou Machado de Assis em parte de suas obras. ${ }^{69}$

Definir o lugar do liberto era uma forma de manter seus privilégios econômicos, políticos, sociais e culturais mesmo após a extinção total da escravidão. Manterem-se mais aquinhoados, letrados, educados à europeia, envolvidos em redes de conhecimento que abriam portas e proprietários de moradas em regiões mais urbanizadas exigia reafirmarem e recriarem o discurso da incapacidade intelectual dos africanos e seus descendentes, do seu desajustamento aos padrões culturais durante as épocas após a abolição. 
É importante ressaltar que esta é a rotinização do conflito racial do pós-abolição. O processo foi silencioso e se reinventou na dinâmica do tempo, a fim de pôr no lugar da subalternidade aqueles que não deveriam ocupar lugares de privilégios. A segunda metade do XIX foi o início da lógica que nos ocupa até os dias atuais.

\title{
Recebido em 08/03/2019 e aprovado em 20/09/2019
}

\section{Resumo}

Este artigo apresenta uma análise, à luz de historiografia referente aos processos de emancipação e pós-abolição no Brasil, de quatro publicações que versam sobre os caminhos para a eliminação gradual da escravidão. Nas páginas analisadas, veem-se propostas e regras que vislumbravam, em larga medida, assegurar os privilégios de proprietários de pessoas escravizadas e definir o lugar dos libertos na sociedade, garantindo que as hierarquias sociais, políticas, econômicas e raciais existentes no período permanecessem nas décadas posteriores. Além do impacto das leis emancipacionistas sobre o futuro de senhores e escravizados em fins do século XIX, os escritos de uma parteira, um progressista, um intelectual e um médico expressaram propostas sobre como conduzir a nação brasileira para um futuro no pós-abolição.

Palavras-chave: pós-abolição - elemento servil - Império.

\begin{abstract}
This article draws on the scholarship around emancipation and post-abolition processes in Brazil in order to analyze four publications that deal with the pathways to the gradual elimination of slavery. These texts advance proposals and rules that envisioned, to a large extent, preserving the privileges of owners of enslaved persons as well as defining the place of freedmen and women in society, ensuring that the existing social, political, economic and racial hierarchies remained in place for the following decades. In addition to assessing the impact of emancipationist laws on the future of masters and enslaved persons in the late nineteenth century, the writings of a midwife, a progressist, an intellectual, and a doctor conveyed proposals on how to lead the Brazilian nation to a post-abolition future.
\end{abstract}

Keywords: emancipation - slaves - Imperial Brazil. 